\title{
Purification of Water using Moringa oleifera Horse radish) Leaf Powder and Seeds Flour.
}

\author{
Emmanuel O. Ahaotu, Reginald E. Uwalaka, Maxwell C. Edih and Pius O. Ihiaha \\ Department of Animal Production and Health Technology, Imo State Polytechnic Umuagwo, Nigeria. \\ Corresponding author: emmaocy@yahoo.com
}

\begin{abstract}
High cost of treated water in the rural communities makes people to resort to readily available water sources which are normally of low quality exposing them to waterborne diseases. The present study was carried out to confirm the effectiveness of seeds flour and leaf powder extracted from mature-dried Moringa oleifera seeds and leaves which are commonly available in most rural communities. During this study, surface water samples were collected for treatment by Moringa seeds and leaves in powdered form, resulting in an effective natural clarification agent for highly turbid and untreated pathogenic water. Application of this low cost Moringa oleifera seeds is recommended for eco-friendly, nontoxic, simplified water treatment where rural and peri-urban people living in extreme poverty.
\end{abstract}

Keywords: (Moringa oleifera seeds and leaves, cationionic protein, clarification agent, antimicrobial activity, human health)

\section{Introduction}

Chemical coagulants like Aluminum sulphate (alum) are used in drinking water treatment plant for purification process (Mangale et al., 2012). This excess use of amount of chemical coagulants can affect human health as aluminum has also been indicated to be a causative agent in neurological diseases such as pre-senile dementia (Amagloh and Benang, 2009). In rural areas people living in extreme poverty are presently drinking highly turbid and microbiologically contaminated water as they lack knowledge of water treatment and also cannot afford the high cost of chemical coagulants.

Moringa oleifera (Moringaceae) is a fastgrowing softwood tree indigenous to Northern India (Leone et al., 2015a). Naturally occurring coagulants are usually presumed safe for human health. All parts of the Moringa tree (leaves, seeds, roots and flowers) are suitable for human and animal consumption.

The leaves, which are rich in protein, minerals, $\beta$ carotene and antioxidant compounds are used not only for human and animal nutrition but also in traditional medicine (Leone et al., 2015b). The seeds contain a significant amount of oil (up to 40\%) with a high-quality fatty acid composition (oleic acid > $70 \%$ ) and after refining, a notable resistance to oxidative degradation will be recorded (Ahaotu et al., 2013a). The oil is commercially known as ben oil. Its properties make it suitable for both human consumption and commercial purposes. Moreover, after oil extraction, the seed cake can be used in waste water treatment as a natural coagulant and also as an organic fertilizer to improve agricultural productivity (Ahaotu et al., 2013b and Mangale et al., 2012). Clean water sources has always been a major problem in many developing countries, especially for the rural poor. Many rural dwellers, since they have no alternative, have to consume surface water either from rivers or rain-fed ponds (Emmanuel et al., 2011 and Boskou, 2011).

Table 1. Proximate Composition of Moringa oleifera seeds

\begin{tabular}{lll}
\hline Nutrients & $\begin{array}{l}\text { Percentage of } \\
\text { Weight }(\text { grams })\end{array}$ & \\
\hline Skin & 35.08 & \\
Seed & 64.92 & \\
Calcium & 0.18 & \\
Phosphorous & 0.69 & \\
Protein & 36.00 & \\
Fat & 32.09 & \\
\hline
\end{tabular}

After mixing one powdered seed in 1 litre of turbid water, all the solids will be coagulated and fallen to the bottom of the container after two hours as shown in Fig 1a below. By then, 98 per cent of the coliform bacteria were removed from the water. The settling occurs in one and the clarified water is stored in the second.

The use of Moringa seeds in water purification has an added advantage over the chemical treatment of water because it is biological and has been reported as edible. Ogunsina et al., (2014) discovered that hardness removal efficiency of Moringa oleifera was found to increase with increasing dosage. These seeds also act as antimicrobial agent against variety range of bacteria and fungi (Rockwood et al., 2013).

Among all the plant materials that have been tested over the years, powder processed from the seeds from Moringa oleifera has been shown to be one of the most effective as a primary coagulant for water treatment and can be compared to that of Alum (conventional chemical coagulant). 
Fig 1a: Water Purifying Properties
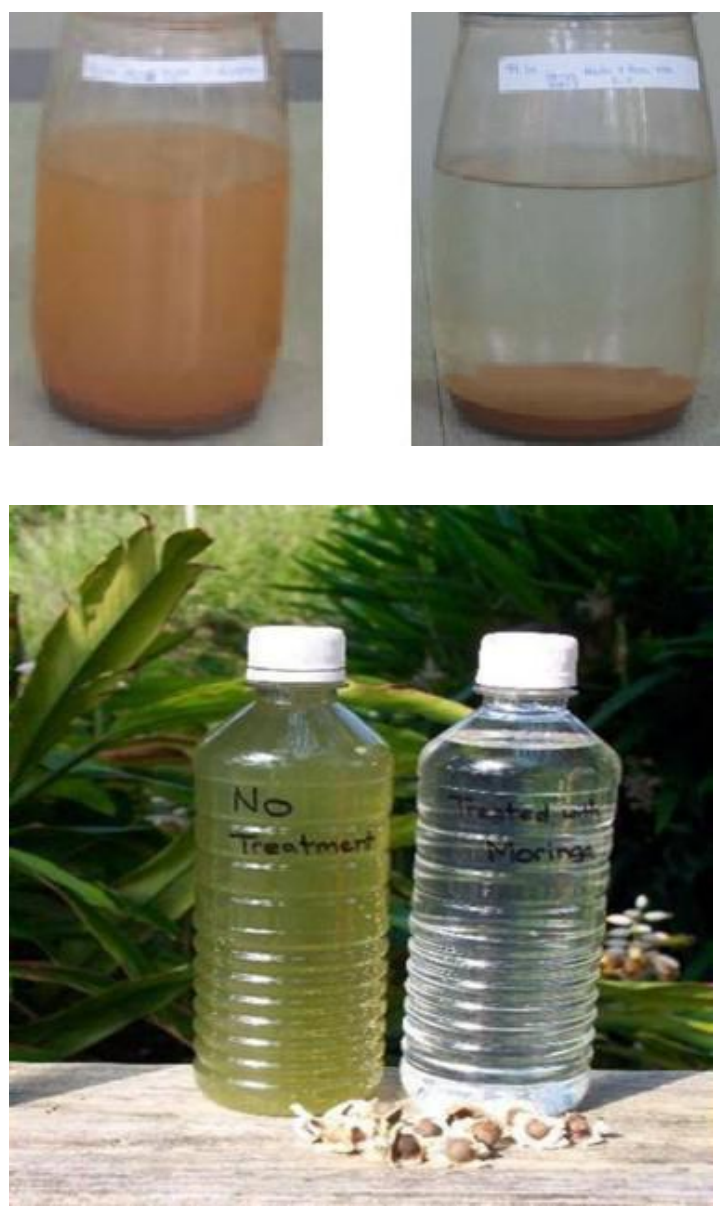

Fig1b. Water Clarity Using Grinded Moringa Oleifera Seeds with Moringa seed powder dirt sinks to the bottom in dirty water.

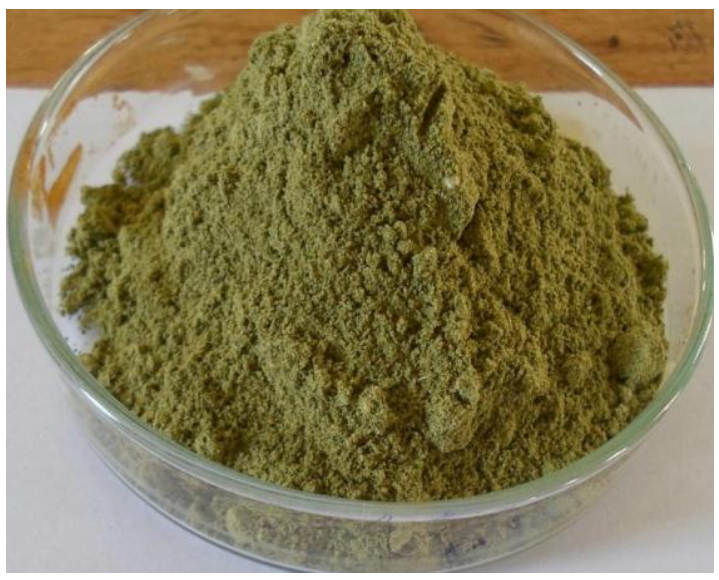

Fig 1 c. Moringa oleifera Leaf Powder

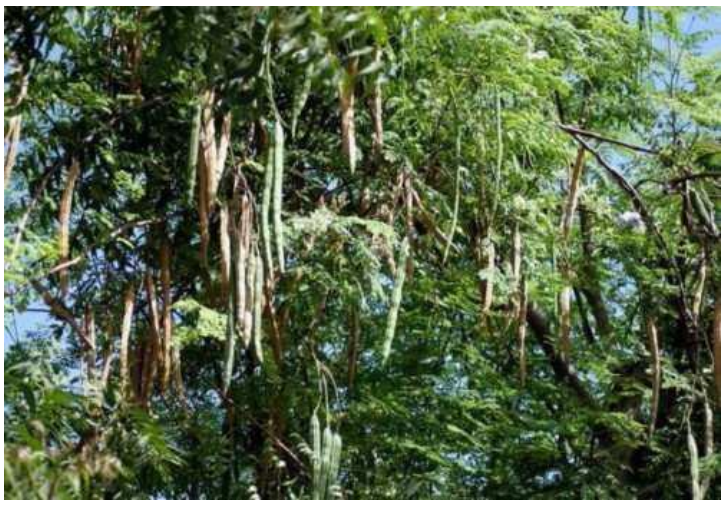

Fig 1 d. Moringa oleifera Tree displaying Mature Pods

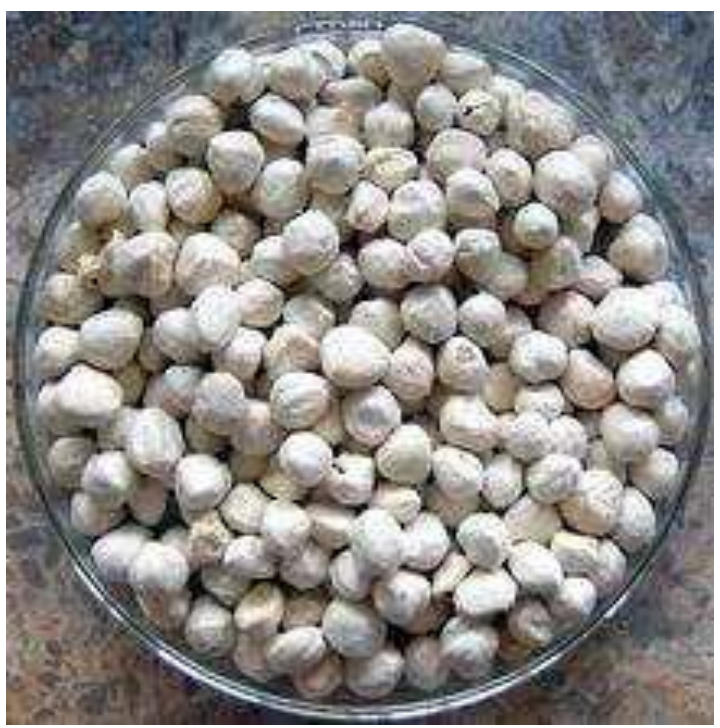

Fig 1e. Moringa seeds without coatings.

\section{Materials and Method}

\section{Collection of Moringa Seeds and Leaves}

The Moringa oleifera seeds and leaves used for this work were obtained from the Forestry unit, Imo State Polytechnic Umuagwo, Nigeria as shown in fig $1 \mathrm{~d}$ and e.

\section{Processing of Moringa Seeds and Leaves}

Moringa oleifera kernels were cleaned to remove stones, dirt, sand and other extraneous materials as shown in (Fig 1 e). The cleaned kernels were cracked by hand to remove the shell from the nuts as shown in (Fig 1 e) above. The seeds were dried in the cabinet oven at $60^{\circ} \mathrm{C}$ for 2 hours, after which it was milled to flour in an attrition mill to obtain a smooth Moringa oleifera seeds flour. Also the horse radish leaves collected were dried at room temperature until the leaves became crispy. The leaves were then sent to a hammer mill to get the powdery form of the leaves as shown in (Fig 1c). The grinded horse radish leaves was mixed with baking soda and water in a container. The mixture 
was then used to remove stained areas (kitchen sink, refrigerator wall and tile walls). Fine powder prepared was directly used as coagulant.

\section{Purification of Water}

Water samples were collected from Ota miri river water near the Department of Animal Production and Health Technology, Imo State Polytechnic Umuagwo, Nigeria was used for the study purpose. Treatment to water was assessed by directly using seed and leaf powder. The water quality parameters were checked before and after treatment. Doses of seed powder which is 50,100 and $150 \mathrm{mg} / \mathrm{l}$ were selected for treatment by supporting table of Micheal Lea Clearing house, Low cost water treatment technologies for developing countries, Ottawa, Canada. (Table 2).

Table 2. Dose range of $M$. oleifera seed powder given by Mangale et al., (2012)

\begin{tabular}{llll}
\hline S/N & $\begin{array}{l}\text { Raw } \\
\text { Turbidity (NTU) }\end{array}$ & $\begin{array}{l}\text { Water } \\
\text { oleifera Range of } \mathrm{M} . \\
\text { Powder (mg/l) }\end{array}$ \\
\hline $\mathbf{1}$ & $<\mathbf{5 0}$ & $\mathbf{5 0}$ \\
$\mathbf{2}$ & $\mathbf{5 0 - 1 5 0}$ & $\mathbf{1 0 0}$ \\
$\mathbf{3}$ & $>150$ & $\mathbf{2 0 0}$ \\
\hline
\end{tabular}

The coagulant was mixed with drinking water sample and kept on the shaker for $45 \mathrm{~min}$ at 110 $120 \mathrm{rpm}$. The settling time was 1 - 2 hours (depending on the water turbidity).

\section{Results and discussion}

Water samples were collected from Otamiri River, following drinking water quality parameters were analyzed before and after the treatment of various doses of Moringa oleifera seed and leaf powder.

Colour. The initial brown colour of the river water sample was completely removed after the treatment of $M$. oleifera seed powder. This suggests that the M. oleifera seeds show absorbent properties. Good clarification is obtained if a small cloth bag filled with the powdered seeds of the moringa is swirled round in the turbid water (Kien et al., 2009 and Amagloh and Benang, 2009).

Acidity. Acidity during the present study was observed to be $35 \mathrm{mg} / \mathrm{l}$ for the river water sample. At various doses of $M$. oleifera, it was observed that the acidity decreased and was present in the range of $5-20 \mathrm{mg} / \mathrm{l}$ within the limits of WHO standards. When the seeds were crushed and added to water, the protein produces positive charges acting like magnets and attracting predominately negatively charged particles leading to maintain acidity within range.
Alkalinity. Alkalinity during the present study was observed to be $104 \mathrm{mg} / \mathrm{l}$. At various doses of Moringa oleifera seed powder, it was observed that the alkalinity reduced after the treatment at $50 \mathrm{mg} / \mathrm{l}$ dose but at higher doses of 100 and $150 \mathrm{mg} / \mathrm{l}$, the alkalinity was increased. The alkalinity observed was in the range of 95-100 mg/l which was within the limit. The Moringa oleifera seed extract appears to have natural buffering capacity. The chemical constituent of the precipitate was however not known, but it was found that alkalinity reduction in the coagulation of water sources was visible in using Moringa oleifera seeds.

Chloride. Chlorides initially were $17 \mathrm{mg} / \mathrm{l}$ in the river water sample, but often treatment with Moringa seed reduced it three fold. This was because cations from Moringa seed attract the negatively charged chloride ions present in water and neutralize the chlorides. Chloride range was 5-9 $\mathrm{mg} / \mathrm{l}$ in water samples and is within limits of drinking water standards (Srivastava et al., 2011).

Hardness. Hardness ranges from 100-170 mg/l after treatment which is within the limits of WHO standards. As a polyelectrolyte it may therefore be postulated that Moringa oleifera removes hardness in water through adsorption and inter-particle bridging (Mishra et al., 2011). These authors further stated that Moringa seed powder as a polyelectrolyte removes hardness in water through adsorption and inter-particle bridging. The higher value for the surface water samples was due to the fact that they contain hardness due to calcium, magnesium and other hardness causing substances. This implies that as the number of hardness increases, the required dosage of Moringa oleifera seed powder increases. SPC (Standard Plate count). SPC means total bacterial count which is calculated quantitatively. Due to high microbial load, drinking water samples are unsafe for drinking purpose. Initial Standard Plate Count was beyond the limit of USPH standards in river water sample. The Moringa oleifera seed powder treatment had an added advantage of reducing microbial load. After the treatment, the numbers of bacterial colonies were reduced with increased dose of Moringa seed powder. However after treatment, SPC which was total bacterial count range was found in between 104 to 105 and is within permissible limit in river water. At 100 and $150 \mathrm{mg} / \mathrm{l}$ dose of Moringa seed powder, the plate shows very few colonies (fig 1b) as treated. It was further more observed that the Moringa oleifera seed powder act as an antimicrobial agent against microorganisms (Kien et al., 2009).

MPN (Most Probable Number). MPN means total coli forms which are calculated quantitatively. The presence of coli forms indicates that the water was feacally contaminated and not safe for drinking 
purpose. Due to coli forms, various waterborne diseases occur and therefore, MPN should be nil for drinking water. In the present study, it was observed that the initial MPN was present beyond the limits of WHO standards. After the treatment, MPN / 100 $\mathrm{ml}$ coli form was decreased from low dose to high level dose of $M$. oleifera seed powder. The MPN was present in the range $20-180$ coli forms $/ \mathrm{ml}$ in all samples after the treatment which indicates that it was above the limits of WHO standards.

\section{Conclusion}

Moringa oleifera seeds acts as a natural coagulant, flocculent, absorbent for the treatment of drinking water. It reduces the total hardness, turbidity, acidity, alkalinity, chloride after the treatment. It also acts as a natural antimicrobial active against the micro-organisms which is present in the drinking water and decrease the number of bacteria. The MPN test had shown positive which indicates the water samples are feacally contaminated and not safe for drinking. MPN test reading was reduced after treatment of higher dose at $150 \mathrm{mg} / \mathrm{l}$ of Moringa seed powder. If we can use combined Moringa oleifera seed powder and chlorine it can give best results and the water can be suitable for drinking.

Moringa oleifera seed is not giving any toxic effect. It is eco-friendly and cheaper method of purification of water and therefore can be used in the rural areas where no facilities are available for the treatment of drinking water. After the treatment of Moringa oleifera seed, sludge gets settled at the bottom of tank.

\section{References}

Ahaotu, E.O, Ezeafulukwe, C.F, Ayo-Enwerem, C.M and Ekenyem, B.U (2013a). Effects of Enzyme Fortified Raw Moringa Seed (Moringa oleifera) Waste Diets on Nutrient Utilization and Haematological Parameters of Broilers. Inter J Appl Sci Engr, 1(1): 25-30.

Ahaotu, E.O, Uwalaka, R.E and Ayo - Enwerem. C.M (2013b). Enhancing Maize Stover utilization by West African Dwarf Sheep using Moringa Oleifera. Inter J Agri Biosci, 2(4): 153-155.

Amagloh, M and Benang, G (2009). "Effectiveness of Moringa oleifera seeds as a coagulant for water purification", University for Development Studies, Faculty of Applied Sciences, Department of Applied Chemistry and Biochemistry, P.O. Box 24, Navrongo, Ghana.

Boskou .D (2011). Vegetable oils in Food Technology. Wiley-Blackwell; Hoboken, NJ, USA. Olive oil; pp. 243-271.
Emmanuel S.A., Emmanuel B.S., Zaku S.G and Thomas S.A (2011). Biodiversity and agricultural productivity enhancement in Nigeria: Application of processed Moringa oleifera seeds for improved organic farming. Biol. J. N. Am. 2:867-871.

Kien, T. W., Azni I., Megat M., Noor M., Johari, T.A., Mohammad, A., Halim, $G$ and Suleyman, A. M (2009). Desalination and Water Treatment, Malaysia, 10 pp. 87-94.

Leone A., Spada A., Battezzati A., Schiraldi A., Aristil J and Bertoli S (2015a). Cultivation, genetic, ethnopharmacology, phytochemistry and pharmacology of Moringa oleifera leaves: An overview. Int. J. Mol. Sci. 16:12791-12835

Leone A., Fiorillo G., Criscuoli F., Ravasenghi S., Santagostini L., Fico G., Spadafranca A., Battezzati A., Schiraldi A and Pozzi F.(2015b). Nutritional characterization and phenolic profiling of Moringa oleifera leaves grown in chad, sahrawi refugee camps, and Haiti. Int. J. Mol. Sci. 16:18923-18937.

Mangale S. M., Chonde S. G., Jadhav A. S., and Raut P. D. (2012). Study of Moringa oleifera (Drumstick) seed as natural Absorbent and Antimicrobial agent for River water treatment. J. Nat. Prod. Plant Resour., 2012, 2 (1):89-100

Mishra G., Singh P., Verma R., Kumar S., Srivastav S., , Jha K.K. and KhosaR. L., (2011). Der Pharmacia Lettre, 3(2): 141-164.

Ogunsina B.S., Indira T.N., Bhatnagar A.S., Radha C., Debnath S. and Gopala Krishna A.G (2014). Quality characteristics and stability of Moringa oleifera seed oil of Indian origin. $J$. Food Sci. Technol. 51:503-510.

Rockwood, J.L, Anderson, B.G and Casamatta, D.A (2013). Potential uses of Moringa oleifera and an examination of antibiotic efficacy conferred by $M$. oleifera seed and leaf extracts using crude extraction techniques available to underserved indigenous populations, Int. J. Phytothearpy Res. 3: 61-71.

Srivastava A., Mittal D., Sinha I., Chakravarty I. and Raja R.B (2011). Annals of Biological Research, (2):227-238.

\section{Acknowledgement}

The authors wish to thank the Executive Director and the entire management of TETFUND, Nigeria for providing funds to conduct present study. 